\title{
Child marriage in Nigeria: (II)legal and (un)constitutional?
}

\author{
Enyinna S Nwauche* \\ Professor, Faculty of Law, Rhodes University, Grahamstown, South Africa
}

\begin{abstract}
Summary
The article refers to a recent article on child marriage in Nigeria, published in this Journal, as a broad context to examine two issues. The first is the statutory elaboration of the constitutional protection of children, and the second is the suggestion that religious marriages trump children's rights in Nigeria's constitutional jurisprudence. These issues are discussed together in the context of the belief that the absence of statutory protection of children is not fatal to their human rights protection, and that neither an Islamic nor any other religious marriage trumps the rights of children in Nigeria. The article recommends a negotiated consensus in determining the minimum age for child marriage, given Nigeria's plural and religious constituents.
\end{abstract}

Key words: Child marriage; Child Rights Act; Child Rights Law; 1999 Constitution

\section{Introduction}

In this article I reflect on two aspects of the article on child marriage in Nigeria by Braimah. ${ }^{1}$ My first concern relates to the nature and extent of statutory elaboration of the constitutional protection of children in a dualist and religiously-plural federal country. My second concern is the view that the 1999 Constitution of the Federal Republic of Nigeria (1999 Constitution) recognises religious marriages as trumps in the Nigerian Bill of Rights jurisprudence. In this regard, I specifically address the contention in Braimah's excellent article that section 61 of Part I of the Second Schedule to the 1999 Constitution

\footnotetext{
LLB LLM (Obafemi Awolowo), BL (Nigerian Law School); enyinnanwaucche@yahoo.com

1 TS Braimah 'Child marriage in Northern Nigeria: Section 61 of Part 1 of the 1999 Constitution and the protection of children against child marriage' (2014) 14 African Human Rights Law Journal 474.
} 
supports the legality of religious child marriages in Nigeria. The concerns raised above are related and will be discussed together in the context of the belief that the absence of statutory protection of children is not fatal for their human rights protection, and neither an Islamic nor any other religious marriage trumps the rights of children in Nigeria. Methodologically, even though this comment draws generally from Braimah's article to provide some of the context important for my comments, it is not a direct refutation of some of Braimah's conclusions in respect of child marriage. In sum, my comments are a modest contribution to the important debate on the nature and structure of the protection of human rights in Nigeria.

\section{Statutory elaboration of human rights: The Child Rights Act and the protection of children in Nigeria}

In this part of my comment I address the effect of a constitutional design that expressly or impliedly relies on statutory elaboration as a means of providing content to human rights in Nigeria, where the protection of children is principally through the Child Rights Act (CRA) and Child Rights Law (CRL) promulgated in many of Nigeria's 36 states. These Acts are domestic manifestations of Nigeria's ratification of the UN Convention on the Rights of the Child $(C R C)^{2}$ and the African Charter on the Rights and Welfare of the Child (African Children's Charter) ${ }^{3}$ pursuant to section 12(1) of the 1999 Constitution, which requires all treaties to be domesticated before they can create domestic legal obligations. ${ }^{4}$ The CRA was promulgated by the National Assembly pursuant to its plenary powers to legislate for the federal capital territory Abuja, ${ }^{5}$ but not for the Federation, since children are part of the residual list in the Nigerian Constitution $^{6}$ and, therefore, within the legislative preserve of states in

Nigeria signed the CRC in January 1990 and ratified it on 16 April 1991.

Ratified by Nigeria on 23 July 2001.

See sec 12(1) of the 1999 Constitution. See also the cases of Registered Trustees of the National Association of Community Health Practitioners of Nigeria \& Others $V$ Medical and Health Workers Union of Nigeria [2008] 2 NWLR (Pt 1072) 575; Fawehinmi $v$ Abacha [2000] 6 NWLR (Pt 660) 228. See also AO Enabulele 'Implementation of treaties in Nigeria and the status question: Whither Nigerian courts' (2009) 17 African Journal of International and Comparative Law 326; CA Nwapi 'International treaties in Nigerian and Canadian courts' (2011) 19 African Journal of International and Comparative Law 38; A Oyebode International law and politics: An African perspective (2003) 9.

5 See sec 299 of the 1999 Constitution.

6 Nigerian constitutional law theory recognises three lists sharing power between the federal and state governments. Two of these lists, the exclusive and concurrent lists, are recognised in the 1999 Constitution, while the third list, the residual list, is consequential. See Attorney-General Abia State \& 35 Others $v$ Attorney-General of the Federation (2002) 3 SC 106. 
the Nigerian Federation in accordance with sections 12(2) and (3) of the 1999 Constitution. ${ }^{7}$ Domestic legislation on matters such as children (that are not on the exclusive legislative list) ${ }^{8}$ requires the consent of the majority of Houses of Assembly of the states of the Nigerian Federation. Even though it became necessary after the National Assembly had legislated the CRA that each of the 36 states do the same, it was thought that the CRA should be a model since it closely followed the CRC. It is important, however, to point out that no state of the Federation is bound to adopt the CRA, ${ }^{9}$ and those that have done so have done it at their discretion. Accordingly, a unique challenge exists in the domestication of treaties in Nigeria where there is a divergence in federal and state legislation. While Nigeria's treaty commitments $^{10}$ may be in issue in such a case, divergent state legislation is constitutional and binding. Even though most CRL adopts the CRA in respect of the definition of a child, there are differences, especially that of the Islamic northern states of the Federation where, instead of the age of 18 stipulated by the CRA, ${ }^{11}$ the physical and psychological condition of the child - evident in the requirement of 'puberty' - is the threshold in determining the capacity to marry. ${ }^{12}$

It is clear from the foregoing that the protection of children in Nigeria appears entirely statutory, and it may be easy to conclude that the Bill of Rights of the 1999 Constitution does not specifically protect

7 See secs 12(2) \& (3) of the 1999 Constitution, which provide: '(2) The National Assembly may make laws for the Federation or any part thereof with respect to matters not included in the Exclusive Legislative List for the purpose of implementing a treaty. (3) A bill for an Act of the National Assembly passed pursuant to the provisions of subsection (2) of this section shall not be presented to the President for assent, and shall not be enacted unless it is ratified by a majority of all the Houses of Assembly in the Federation.'

8 See sec 4(2) of the 1999 Constitution.

9 The position would have been different if the national domestication legislation were within the legislative competence of the federal government. Thus, in the case of the domestication of the African Charter through the African Charter on Human and Peoples' Rights (Ratification and Enforcement) Act ch A9 Laws of the Federation of Nigeria 2004 (Nigerian African Charter Act), no state legislation would be permissible and, if made, could be impugned on the ground of conflict with the national legislation. See V Ayeni 'The impact of the African Charter and Women's Protocol in Nigeria' in Centre for Human Rights The impact of the African Charter and Women's Protocol in selected African states (2012) 121.

10 See Abacha (n 4 above).

11 It is important to note that three provisions of the CRL deal directly with child marriages. While sec 21 provides that no person under the age of 18 years is capable of contracting a valid marriage and, accordingly, a marriage so contracted is null and void and of no effect whatsoever, sec 22(1) provides that no parent, guardian or any other person shall betroth a child to any person. Sec 22(2) provides that a betrothal in contravention of subsec (1) of this section is null and void. Sec 23 criminalises aspects of child marriage and provides that a person who marries a child or to whom a child is betrothed or who promotes the marriage of a child or who betroths a child, commits an offence and is liable on conviction to a fine or imprisonment for a term of five years or to both such fine and imprisonment.

12 See, eg, S Sawyer et al 'Adolescence: A foundation for future health' (2012) 379 Lancet 1630. 
children except to the extent that they may be described as human beings. This erroneous contention perhaps is fuelled by the provisions of section 17(3)(f) of the non-justiciable chapter two of the 1999 Constitution (Fundamental Objectives and Directive Principles of State Policy) which directs the policy of the Nigerian state towards ensuring that children, young persons and the aged are protected from any exploitation whatsoever, and against moral and material neglect. The idea that the protection of children is exclusively statutory cannot be supported on any juridical ground. The text relating to protected rights in Nigeria's Bill of Rights begins with the word 'any person', consistent with the fact that all persons in Nigeria, including children, are beneficiaries of the rights contained therein. That children are not specifically provided for may have been an honest omission, but in no way means that they have no protection in the states that have either not promulgated the CRA, or have CRL that is inconsistent with Nigeria's treaty obligations. There is no special mention of 'women' in the Nigerian Bill of Rights, yet it would appear absurd to say that only men are entitled to the rights therein. Even though the 1999 Constitution describes the subjects of its protection as 'individual' in section 34 and 'citizen' in sections 41 and 42, the rest of the Bill of Rights uses the term 'person' in such a way that the words 'individual' and 'person' mean the same thing. It is obvious that children are contemplated as 'individuals' and 'persons'. It is also important to note that the 1999 Constitution does not define 'person' and 'individual' and uses the term 'citizen' for the purposes of chapter three as a category of 'person'. For example, section 25(1) in chapter three provides:

The following persons are citizens of Nigeria by birth, namely (a) every person born in Nigeria before the date of independence, either of whose parents or any of whose grandparents belongs or belonged to a community indigenous to Nigeria: Provided that a person shall not become a citizen of Nigeria by virtue of this section if neither of his parents nor any of his grandparents was born in Nigeria; (b) every person born in Nigeria after the date of independence either of whose parents or any of whose grandparents is a citizen of Nigeria; and (c) every person born outside Nigeria either of whose parents is a citizen of Nigeria.

From this definition it is clear that children are persons first, and citizens if they meet the citizenship requirements of the 1999 Constitution. To imagine, therefore, that children are not protected by the 1999 Constitution would fly against all canons of constitutional interpretation and would pander to technicalities. As the Nigerian Supreme Court has consistently stressed, constitutional interpretation should strive to do away with technicalities and seek substantial justice. $^{13}$

13 See Attorney-General of Bendel State $v$ Attorney-General of the Federation (1982) 3 NCLR 1; The State $v$ Gwonto (1983) 1 SCNLR 142; and Aliu Bello $v$ Attorney-General of Oyo State (1986) 12 SC 1. 
It is plausible that the idea of statutory protection of children's rights is an unintended outcome of the laudable advocacy of the United Nations Children's Fund (UNICEF). For example, in its campaign literature, UNICEF states that '[i]ssues of child rights protection are on the residual list of the Nigerian Constitution, giving states exclusive responsibility and jurisdiction to make laws'. ${ }^{14}$ The use of the phrase 'exclusive' conveys the meaning that children's rights are at the mercy of states, which is not entirely correct.

Another report echoes this sentiment: ${ }^{15}$

To date, only about 20 among the 36 states in Nigeria have enacted corresponding state laws of the Child Rights Act via the state legislative arms of government. As such, the protection of children's rights (at least by law) as envisaged by the regime of the CRC and the ACRWC is not guaranteed across the board all over Nigeria since the governments of the states where the Child Rights Act has not been enacted or translated into law, are under no obligation to fulfil the protection of those rights.

Again, it is clear from the above comment that the protection of children is predicated on the statutory scheme and neglects the Bill of Rights. It is important to draw attention to other statutory schemes prohibiting conduct that is potentially implicated in child marriage and, therefore, important in states without CRL. Thus, section 361 of Nigeria's Criminal Code ${ }^{16}$ prohibits, on the pain of a seven-year term of imprisonment, the taking away or detention of a female of any age against her will with the intent to marry her or have sexual intercourse with her or to encourage another to marry her or have sexual intercourse with her. There is also the possibility that child marriage could result in the offence of rape, especially where there is no consent or where it is doubtful whether a child can be considered capable of consenting to marriage, thereby destroying the immunity granted to a husband by Nigerian law. ${ }^{17}$ In addition, the Penal Code applicable in Northern Nigeria and the Criminal Code set the ages of $14^{18}$ and $13^{19}$ respectively as the age that a child is incapable of giving consent and, therefore, a child marriage involving a girl of this age could amount to a crime. Furthermore, the Trafficking in Persons (Prohibition) Law Enforcement and Administration Act 2003 also criminalises sexual intercourse with a person under 18 years and

14 See UNICEF 'Nigeria Fact Sheet: Child rights legislation in Nigeria' http://www. unicef.org/nigeria/Child_rights_legislation_in_Nigeria.pdf (accessed 3 February 2015).

15 See The Africa Child Policy Forum 'The harmonisation of children's laws in West and Central Africa' 84, http://www.africanchildforum.org/clr/Harmonisation\% 20of\%20Laws\%20in\%20Africa\%/Publications/supplementary-acpf-harmonisationcb-wc_en.pdf (accessed 12 September 2015). See also CLEEN 'Rights of the child in Nigeria: Report on the implementation of the Convention on the Rights of the Child' http://www.cleen.org/nigeria_ngo_report_OMCT.pdf (accessed 3 February 2015.)

16 Criminal Code Act Cap C34 Laws of the Federation of Nigeria, 2004.

17 See secs $6 \& 282(2)$ of the Criminal Code.

18 Sec 282(1) Penal Code.

19 Sec 218 Criminal Code. 
could, therefore, be the basis of criminal prosecution of persons involved in child marriages.

One of the fundamental constructs of the Nigerian Constitution is its declaration in section 1(1) that '[t]his Constitution is supreme and its provisions shall have binding force on authorities and persons throughout the Federal Republic of Nigeria'. Section 1(3) further provides that '[i]f any other law is inconsistent with the provisions of this Constitution, this Constitution shall prevail and that other law shall to the extent of the inconsistency be void'. Nigerian courts have interpreted this provision in a number of cases, including AttorneyGeneral of Lagos State $v$ Attorney-General of the Federation ${ }^{20}$ and Inspector-General of Police $v$ All Nigeria Peoples Party \& Others ${ }^{21}$ in a literal sense, and have struck down state and federal legislation that breaches the Nigerian Constitution. ${ }^{22}$ The supremacy of the Nigerian Constitution subjects all statutes, including the CRA and CRL, to the tenor of its provisions generally, and to the rights contained therein. For example, a Nigerian court would be within its rights to review a contention that all or some parts of a CRL or a CRL conflict with the Bill of Rights. Rights available to children in the Bill of Rights are also applicable in states that have no CRL. It is therefore difficult to imagine that children have no protection in states that have no CRL. Their protection is contained in the Bill of Rights. It is, therefore, important to briefly review the rights which potentially protect children from child marriage against the background that all rights in the Bill of Rights potentially protect children. First, section 34 of the 1999 Constitution provides that every individual is entitled to respect for the dignity of his person and no person shall be subjected to torture or to inhuman or degrading treatment. Second, section 35(1) protects the personal liberty of the girl child. Third, section 37 protects the right to private and family life of the girl child, while section 40 protects the right to peaceful assembly and association of the girl child. Given the widespread evidence of the effects of child marriage, there is no doubt that a Nigerian court would readily find that child marriage is contrary to the right to freedom from inhuman and degrading treatment. Apart from the Nigerian Bill of Rights, article 18(3) of the African Charter on Human and Peoples' Rights (African Charter) requires state parties such as Nigeria to ensure the protection of the rights of the child as stipulated in international declarations and conventions. It is important to remember that Nigerian courts have held that the Nigerian African Charter Act is

20 (2003) 12 NWLR (Pt 833) 1.

21 (2007) AHRLR 179 (NgCA 2007).

22 See INEC v Musa (2003) 3 NWLR (Pt 806) 72 and Attorney-General Abia State $v$ Attorney-General of the Federation (2006) 16 NWLR (Pt 1005) 265. 
superior to national legislation. ${ }^{23}$ There is therefore no juridical basis why the Nigerian African Charter Act cannot be used to protect children in Nigeria. The dearth of such rights-based litigation is disturbing and surprisingly absent in the articulation of a protective mandate for children in Nigeria. Perhaps the reason may be found in the discussion in the next section, which seeks to demonstrate that Islamic and customary marriages are subject to the 1999 Constitution. It may well be that a contrary opinion, such as that of Braimah, is the reason for the reluctance to deploy relevant rights to protect the Nigerian child.

Having established that the Bill of Rights applies to all parts of Nigeria and to all persons, including children, it is important to dwell on the nature and extent of this protection in light of the design of the Bill of Rights as articulated by Nigerian courts.

\section{Religious marriages as trumps}

In this section I address the suggestion that, by virtue of section 61 of Part 1 of the Second Schedule to the 1999 Constitution, ${ }^{24}$ Islamic and customary marriages are not subject to any restrictions. Braimah, for example, contends that ' $[t]$ here is a strong argument to be made that child marriage is not illegal in Nigeria under Second Schedule Part 1 item 61 of the Nigerian Constitution'25 which, as part of the exclusive legislative list, endows plenary powers on the formation, annulment and dissolution of Islamic and customary marriages on states of the Federation because such marriages become part of the residual legislative list. He continues: ${ }^{26}$

When a person marries a child under Islamic law in Northern Nigeria and is consequently in contravention of the Child Rights Act, such a person cannot be prosecuted because the federal government would be interfering with an Islamic marriage and would be in violation of Part 1 Section 61 of the 1999 Constitution. Therefore, in relation to child marriage, Part 1 Section 61 of the 1999 Constitution renders the Child Rights Act useless, as the 1999 Constitution serves as the supreme law of the land in Nigeria, overriding all other legislation.

It would appear that while he is correct that the CRA may not enable a prosecution for child marriage, it is not because of Part 1 section 61 of the 1999 Constitution, but largely - and this relates to criminal

23 See Oshevire v British Caledonian Airways Ltd (1990) 7 NWLR (Pt 163) 607 and UAC (NIG) Lyd v Global Transport SA (1996) 5 NWLR (Pt 448) 291. See OJ Ojigho 'Evaluating the application, implementation and enforcement of international human rights instruments and norms in Nigeria' (2005) 31 Commonwealth Law Bulletin 109.

24 Sec 61: 'The formation, annulment and dissolution of marriages other than marriages under Islamic law and customary law including matrimonial causes relating thereto ...'

25 Braimah (n 1 above) 485

26 As above. 
prosecution - because there is neither a CRL nor other legislation that criminalises child marriage in the manner of the CRA. For example, section 15(1) of the Jigawa State CRL 2006 prohibits child marriage but defines a child in section 2(1) of that Law as a person below the age of puberty. ${ }^{27}$ Accordingly, it would be correct to declare that Jigawa State criminalises child marriage to the extent that a girl has not reached puberty. This is possible because puberty is defined in section 2 of the Jigawa Law as the age at which a person is physically and physiologically capable of consummating a marriage. In addition, a court is to determine - according to the provisions of section 15(1) - the puberty of the child bride according to the circumstances of each case.

The lack of appropriate legislation immunises Islamic or customary marriages from the Bill of Rights because Part 1 of the Second Schedule to the 1999 Constitution merely determines how constituent parts of a federal Nigeria share power. ${ }^{28}$ Such exercise of power is subject to other parts of the Constitution, including the Bill of Rights, by reason of the supremacy clause of the 1999 Constitution. It is important to remember that the radical legislative changes that introduced Islamic criminal law in the northern states of Nigeria acknowledged the supremacy of the 1999 Constitution. ${ }^{29}$ Accordingly, CRL is subject to the Bill of Rights in a manner in which the Bill of Rights could be a sword and shield in respect of prosecutions for child marriage. CRL that permits child marriage (understood in the CRA form or elsewhere) could be impugned by the right to freedom from inhuman and degrading treatment, the right to personal liberty, the right to family and private life and the right to freedom of association, and struck down as unconstitutional. On the other hand, it is possible that the Bill of Rights could be used as a shield in the sense that relevant rights, such as the right to freedom of religion protected by section 38 of the 1999 Constitution, and the right to private and family life, become the basis of a defence to such criminal prosecution. As a shield, the first step is to acknowledge that Islamic and customary marriages are subject to the relevant human rights and that legislation such as the CRL could be struck down because of breaches of parts of the Bill of Rights and, as such, may be unconstitutional.

The prosecution of an Islamic or customary marriage alleged to be a child marriage is, in effect, a clash between the right to freedom of religion, possibly in favour of the husband, and other rights such as the right to personal liberty and the right to freedom from inhuman

27 See, eg, sec 27 of the CRL 2010 of Niger State (a state in Northern Nigeria), which provides that where there is a conflict involving questions of Islamic law with any of the provisions of the CRL, Islamic personal law shall prevail.

28 See BO Nwabueze Federalism in Nigeria under the Presidential Constitution (1983) 39.

29 See generally P Ostien et al (eds) Comparative perspectives on Shari'ah in Nigeria (2005). 
and degrading treatment. The marriage of a senator, Yarima, to a 13 year-old Egyptian girl raised the question whether the right to freedom of religion trumps the CRA. In an apparent reaction to a request by Nigeria's National Human Rights Commission for intervention by the Senate and the House of Representatives (the National Assembly), the Supreme Council for Shari'a in Nigeria (Council) instituted an action against the federal government and National Assembly before a Federal High Court in Abuja over Senator Yarima's controversial marriage. ${ }^{30}$ The Council also sought the nullification of some aspects of the CRA 2003, including section 21 (setting the minimum age of marriage at 18 years and declaring any such marriage null and void), which she alleged was not consistent with Islam and the practice of Shari'a, as well as Yarima's right to a private and family life, which she argued could not be subjected to invasion, intrusion or interference by any person, group of persons or institutions. In a 13-paragraph affidavit in support of the suit, the Council claimed that the Holy Quran and the traditions of the Holy Prophet Muhammad were in support of Yarima's marriage to the girl as his fourth wife. As stated above and contextualised by the Yarima incident, the human rights pleaded in this case in defence of child marriages suggest that a child is deprived of these rights. Since a child bride is entitled to the same rights as her husband, the criminal prosecution of an Islamic or customary child marriage appears to be a classic case of a clash of human rights.

The resolution of this clash is not an easy one, but would surely involve a proportionality analysis where Nigerian courts weigh the competing interests of the child and husband. It is alleged, as in the Yarima incident, that the child has no rights that trigger the derogation of rights in terms of section 45 of the 1999 Constitution. The argument may be cast in this way: Since section 45 of the 1999 Constitution provides that nothing in the right to private and family life (section 37), the right to freedom of thought, conscience and religion (section 38), the right to freedom of expression and press (section 39), the right to peaceful assembly and association (section 40) and the right to freedom of movement (section 41) shall invalidate any law that is reasonably justifiable in a democratic society (a) in the interests of defence, public safety, public order, public morality or public health; or (b) for the purpose of protecting the rights and freedoms of other persons, it may be alleged by the girl child that the CRA and CRL qualify as such law. The husband, of course, could argue, as in the Yarima incident, that this legislation does not reach the threshold to limit the right to freedom of religion as well as the right to private and family life. As stated above, a proportional or derogation analysis clearly shows that Islamic

30 See K Nwezeh 'Yarima-Shari'a Council drags FG, National Assembly to court' 4 June 2010, http://www.allafrica.com/stories/201006071572.html (accessed 4 March 2015); A Ukwuoma Child marriage in Nigeria: The health hazards and socio-legal implications (2014) 51. 
marriages are not trumps and absolutes. The substance of Islamic and customary marriages depends on rights which, in their interaction with other rights, may be found to be unconstitutional. A while ago, the Nigerian Supreme Court determined the limited scope of the right to freedom of religion and the right to privacy in Medical and Dental Practitioners Disciplinary Tribunal v Okonkwo. ${ }^{31}$ The Court held:

The right of freedom of thought, conscience or religion implies a right not to be prevented, without lawful justification, from choosing the course of one's life, fashioned on what one believes in, and a right not to be coerced into acting contrary to one's religious belief. The limits of these freedoms in all cases are where they impinge on the rights of others or where they put the welfare of society or public health in jeopardy.

There is, therefore, sufficient juridical basis to conclude that the rights to freedom of religion and to private and family life do not trump the CRA or CRL in all instances. The circumstances of each case will determine whether this is the case. It is therefore evident that in states that have not enacted child rights legislation, an Islamic marriage could still be unconstitutional based on the arguments set out above.

Even though religious marriages are not trumps, they call for a nuanced consideration of their impact and, in the context of this article, require a determination of what qualifies as a child marriage, which is relevant in determining the extent to which the right to freedom of religion justifies or negates such a marriage. The use of 'puberty' as a threshold for child marriage invites a consideration of whether biological characteristics $s^{32}$ are as relevant as age in determining the capacity to marry. ${ }^{33}$ Comparative perspectives from India indicate that 'puberty' has been used as a threshold in determining when a girl child is fit for marriage. Accordingly, it may be submitted that age could be a significant but not exclusive factor in determining the capacity to marry. It appears plausible that the age of marriage could be negotiated in Nigeria. The importance of introducing some flexibility in the age a child may be married is evident in constitutional and statutory provisions that recognise a lower CRA-mandated age in Nigeria. First, section 29(4)(b) of the 1999 Constitution provides that '[a]ny woman who is married shall be deemed to be of full age'. ${ }^{34}$

31 (2001) 7 NWLR (Pt 711) 206

32 See Labinjoh $v$ Abake 5 NLR 3 and Folata $v$ Dawomo (1970) NWLR 105, where the courts held that contractual capacity of a child in Islamic law depends on physical capacity and maturity.

33 See MA Ambali The practice of Muslim family law in Nigeria (2003) 155.

34 It should be noted that sec 29(4)(b) concerns the renunciation of citizenship. See also A Onuora-Oguno 'Constitutionalising the violation of the girl child in Nigeria: Exploring constitutional safeguards and pitfalls' 5 August 2013 Oxford Human Rights Hub http://www.ohrh.law.ox.ac.uk/constitutionalising-the-violation-of- thegirl-child-in-nigeria-exploring-constitutional-safeguards-and-pitfalls/ (accessed 4 March 2015). 
Second, the CRL of Akwa Ibom State in the south of Nigeria defines a child as a person under 16 years of age. ${ }^{35}$ In respect of Muslim Nigeria, it would appear wrong to describe Muslims as a monolithic community agreed on child marriages of girls under 18 . To do that is to ignore the realities of the struggle within religious communities to overcome practices such as child marriages that would conform to orthodoxy. It is also to ignore the fact that the threshold of puberty offers a real opportunity to engage Muslim scholarship and hierarchy in, for example, finding a threshold. It could be suggested, for example, that a girl below 15 would not pass this threshold. Accordingly, the marriage of a girl between the ages of 15 and 18 years could be valid on the understanding that the girl is mature and understands the consequence of her actions. Comparative perspectives from India ${ }^{36}$ reveal that the threshold of puberty is the age of 15 , and a marriage at that age is voidable ${ }^{37}$ until the child is 18,38 which is the age of consent. This is also the position of Islamic law in India. ${ }^{39}$ An-Na'im has correctly argued that many interpretations exist in Islamic communities and that an engagement with progressive forces in these societies would achieve an interpretation of Islam that recognises the dignity of all persons ${ }^{40}$ which, of course, includes children.

Third, the best interests of the child, recognised in the CRA and also in child rights legislation by the Nigerian judiciary in Williams $v$ Williams ${ }^{41}$ and Odogwu $v$ Odogwu, ${ }^{42}$ are also relevant in determining an appropriate minimum age for child marriage. In Odogwu, ${ }^{43}$ the Nigerian Supreme Court recognised the happiness and psychological development of a child as crucial in determining custody. It seems appropriate that the same considerations also apply in cases of child marriage. It is entirely possible that a child between the ages of 15 and 18 years could be happily married.

The importance of a negotiated national minimum age for child marriage in Nigeria cannot be overstated, given the widespread

35 See 'Akwa Ibom State Child Rights Law' http://www.aksg online.com.ws)33.alentus.com/child_rights_law.aspx (accessed 3 March 2015).

36 See, eg, Idris v State of Bihar 1980 Crl LJ 764; Begum v State of Delhi WP (CRL) 446/ 2012.

37 See sec 3(1) of the Prohibition of Child Marriage Act 2006, which declares a child marriage as voidable at the instance of the child.

38 Sec 2(a) of the Prohibition of Child Marriage Act 2006 declares a child as one who has not attained the age of 18 .

39 See also Furquan $v$ State WP(CRL) 1025/2012.

40 See, eg, A An-Na'im 'Human rights in the Muslim world: Socio-political conditions and scriptural imperatives' (1990) 3 Harvard Human Rights lournal 13. See also I Ogunniran 'Child Rights Act versus Shari'a law in Nigeria: Issues, challenges and way forward' (2010) 30 Children's Legal Rights Journal 62-80.

41 (1987) 7 NWLR (Pt 252) 187.

42 (1992) 2 NWLR (Pt 252) 539.

43 Odogwu (n 42 above) 589-560. 
recognition of the ills of child marriage. ${ }^{44}$ It is necessary to work from and within Nigerian Muslim communities to agree on a minimum age for child marriage.

\section{Concluding remarks}

The question of child marriage in Nigeria is intricately connected with the nature and extent of the protection of human rights in a multicultural and multi-religious constitutional democracy torn between different perspectives and ends. One perspective protects certain rights of human beings, including children, because they are human beings in the strongest liberal tradition, while the other perspective promotes the norms of the community that men, women and children are born into - religious or cultural communities - that often subordinate the interests of its members to the norms of the community. Child marriages in Nigeria illustrate how the material base of society affects the quality of protection that the recognition of human rights brings. It illustrates how the social and legal complement each other in the protection of human rights. Resolving Nigeria's religious pluralism within its socio-economic context is a challenge that requires negotiations and reasoned consensus that would not thrive in vilifying the 'other'. The struggle to ensure that child marriages are eradicated and/or curtailed would be significantly enhanced by an engagement with all communities to raise awareness of the social hazards of child marriages, thereby informing normative consensus on the appropriate minimum age for the marriage of a girl child.

44 These ills are discussed in I Ogunniran 'Child bride and child sex: Combating child marriages in Nigeria' (2011) 2 Nnamdi Azikiwe University Journal of International Law and Jurisprudence 85 